\title{
Poetic Dialogue from the Periphery of World Literature: Goethe's Faust and the Korean Novel Kumo-shinwha
}

\author{
YOUNG-AE CHON
}

\begin{abstract}
A short but cardinal passage of Goethe's Faust is the rhymed dialogue between Faust and Helen at their first encounter: the depiction of the very idealistic encounter consists of the process by which the ancient Greek mythical figure Helen learns about the difference and charm of the German poetic language, as well as its formal practices explained and guided by Faust. This passage is not only a description of the meeting of Helen and Faust but also, at the same time, verses on poetry and poetics.

This remarkable passage leads us to look into other cases in world literature. With this inquiry I have found out many similar cases in the literature of my own country and of other East Asian countries, Japan and China. As an example, here is presented a highly sublime poetic dialogue, drawn from an outstanding work of premodern Korean literature, the very first Korean "novel" Kumo-shinhwa, from the mid-fifteenth century: an exchange of ekphrasis, verses of picture description. With its perfect, more than perfect, rhyme, the poetic dialogue presents the symbolized union of two persons as a matter of course. By means of this poetic dialogue it will be pointed out how a standard canon does not remain itself but finds its incessant dialogues on behalf of other rather hidden works. Or in short: how the margin shifts itself through exchanges and translations.
\end{abstract}

Keywords: poetic dialogue; Faust and Helen; Kumo-shinwha; Genji Monogatari; Xixiangji; palindrome; Manfred Winkler; Fuad Rifka; Galsan Tschinag

\section{Power of Poetry}

"Why are some works 'sorted out', to be included in the canon, while others, on the contrary, have been destined to oblivion and obscurity?" The question raised at the conference has been my own question for many years. Yet, my question was a little differently formulated: From where comes the power of poetic words which remains and is at work? In pursuit of this question I have written four books in German. The first of those begins with a quote in Korean: 
Poetic Dialogue from the Periphery of World Literature

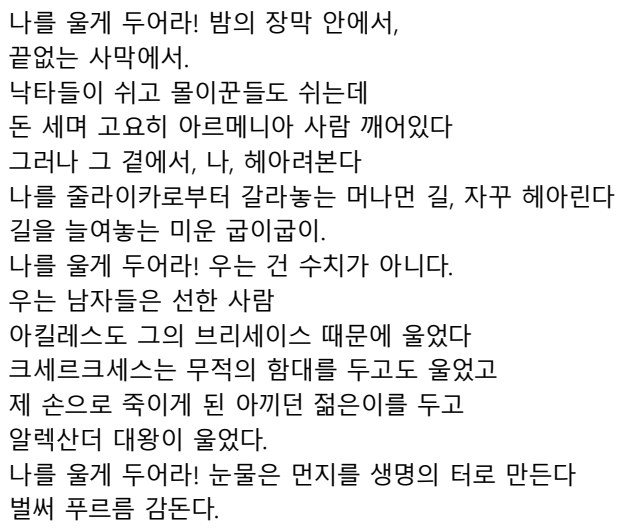

When I was still a middle school student, the time when one reads everything which comes within reach, I encountered by chance these verses - in Korean translation, as quoted - without having any clue about who the author was and even what the title was. (The poem has no title.) Somehow the poem had remained vague in my mind since then. After more than thirty years I encountered it again - to my great surprise. At the time I was just going through the hardship of reading Goethe's West-östlicher Divan in the original: 239 poems and long prose: the still decisive discourse on the Orient, its history, culture and poetry. This poem was in the first edition of West-östlicher Divan (1819) excluded by Goethe himself because of - for his own eyes - an excessive amount of emotion. However, it can now be found in most editions of Goethe's works, posthumously reincluded by the editors. The German original of the poem sounds as follows:

Lasst mich weinen! Umschraenkt von Nacht, In unendlicher Wüste.

Camele ruhn, die Treiber desgleichen, Rechnend still wacht der Armenier:

Ich aber, neben ihm, berechne die Meilen

Die mich von Suleika trennen, wiederhole

Die wegverlängernden Aergerlichen Krümmungen.

Lasst mich weinen! Das ist keine Schande.

Weinende Männer sind gut.

Weinte doch Achill um seine Briseis!

Xerxes beweinte das unerschlagene Heer, Uber den selbstgemordeten Liebling

Alexander weinte.

Lasst mich weinen, Thraenen beleben den Staub.

Schon grunelts. (Goethe 1994: 602) [sic!] 
$\mathrm{CHON}$

Yes, this quote opens the book which led to my attempt to find a way to the great poet, showing the power of poetic words which once fascinated a reader far distant from the origin of the poem - overcoming the great distance in both time and space. My book "Sage denn, wie sprech ich auch so schön?" Zur Macht der Poesie bei Goethe ("Tell, Then, How Can I Speak with Such Fair Art?" On the Power of Poetry at Goethe”, 2011) describes a kind of gallop through the whole poetic works of Goethe, and this gallop ends with diverse interpretations of Faust, including, for example, a religiously conditioned problem of translation and a Buddhist interpretation of the last scene, among others. Finally, the book testifies to a long way from the fascination by a single poem to lifelong research: I have translated Gedichte, whole poems in the first volume of Hamburger Ausgabe, West-östlicher Divan, Dichtung und Wahrheit, Faust I \& II, and written research books on those in Korean as well as in German (Chon 2011).

From where comes the power of poetic words? - This question was not only mine, but also Goethe's; he apparently raised this question - in Faust - and at the same time gave his answer in the form of a dialogue: the Greek figure Helen is fascinated by the sound of the foreign German rhyme and asks Faust. What follows is the dialogue in the German original and its English translations by Walter Arndt and David Constantine.

HELENA. So sage denn, wie sprech 'ich auch so schön?

FAUST. Das ist gar leicht, es muß von Herzen gehen.

Und wenn die Brust von Sehnsucht überfließt, Man sieht sich um und fragt -

HELENA. wer mitgenießt.

FAUST. Nun schaut der Geist nicht vorwärts, nicht zurück, Die Gegenwart allein

HELENA. ist unser Glück.

HELEN. Tell, then, how can I speak with such fair art?

FAUST. It's easy, it must well up from the heart,

And when the breast with longing overbuoys,

One looks about and asks -

HELEN. who shares our joys.

FAUST. Now seeks the mind no forth or back from this, Alone the present moment -

HELEN. is our bliss.

HELEN. In such sweet speaking how shall I take part?

FAUST. Easy enough. It must come from the heart And when from there the feelings overflow 
I look and ask ...

HELEN. from whose glad heart also?

FAUST. We let go past and future then and press

All in the here and now ...

HELEN.

our happiness. (Goethe 2005: 163)

This rhymed dialogue between Faust and Helen at their first encounter shapes a short, but cardinal passage in Faust II: the depiction of the very idealistic encounter consists of the process by which the ancient Greek mythical figure Helen learns about the difference and charm of the German poetic language, as well as its formal practices explained and guided by Faust. This passage is not only a description of the meeting of Helen and Faust, but also verses about poetry and poetics, at the same time.

That my naïve question was already taken up by Goethe to depict moreover - a core scene. The fact itself leads me to a deeper investigation into the theme. I have examined where a similar case could be found.

\section{Discovery of One's Own Tradition}

A similar case was to be found near, the nearest near: in a premodern Korean classic, the very first novel in Korea: Kumo-shinwha [Mt. Kumo Tale] from the middle of the $15^{\text {th }}$ century, written in Chinese letters. (The Korean alphabet was invented in 1443; but the intellectuals still wrote in Chinese - similar to the situation of Latin in Europe.) This Korean case was - again to my surprise and surely also in a formal sense - even more elaborated.

The novel is set in the traditional premodern Korean society which still did not know about free love: from the age of seven, boys and girls were not allowed to be alone in the same room together. At that time a very clever young couple develops highly poetic, lovely strategies to get together: they secretly exchange poems - and it comes finally to a rendezvous. Their meeting is indirectly described - in a form of ekphrasis, the poetic description of pictures: On the pictures hanging in the young lady's room, to which men have no access, or perhaps also on an imaginary picture each recites one's own poem. I show you how subtle this description in verse is:

Choi [young lady]:

曲欄下壓芙蓉池 池上花叢人共語 香霧霏霏春融融 製出新詞歌白 月轉花陰入㲘毛抙 共挽長條落紅雨 風攪清香香襲衣 賈女初踏春陽舞 羅衫輕拂海棠枝 驚起花間宿賏鳥武
Ri [young scholar]:

誤入桃源花爛漫 多少情懷不能語 翠鬤雙綰金釷底 楚楚春衫栽綠 東風初拆並帶花 莫使繁枝戰風雨 飄飄仙袂影婆乷 叢桂陰中素娥舞 勝事未了愁必隨 莫製新詞敎鸎武鳥 
$\mathrm{CHON}$

Here are two poems side by side: the first one is recited by the host, the young lady from a noble family, and the other by the guest, a young scholar. Both poems have rhymes, not only in each poem, but also both share rhymes, and to be precise - every line of two poems ends with the same Chinese character. (Here marked by the same color.) And the same character, a noun, has in each poem a different adjective (a Chinese character next to the last; here marked by blue color). But each poem's last line has not one but two similar characters: it is - without any differentiation - in the completely identical rhyme.

Choi:

曲欄下壓芙蓉池 池上花叢人 香霧霏霏春融融 製出新詞歌困

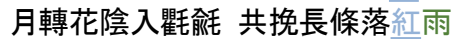
風㩖清香香襲衣 賈女初踏春陽舞 羅衫輕拂海棠枝 驚起花間宿䴍鵡
Ri:

誤入桃源花爛漫 多少情懷不能 翠憝雙綰金釵底 楚楚春衫栽線 東風初拆並帚花 莫使繁枝戰風雨 飄飄仙袂影婆乷 普桂陰中素娥舞 勝事未了愁必隨 莫製新詞敎劕武鳥 (mocking bird)

Moreover, we can read the rhymed words at the end of every line not only horizontally, but also vertically as an acrostichon; through which one more field of view opens itself. This alludes to the final unification of the couple. They begin with 'words'. To be precise, 'sharing words' become 'competent words' [共語-能語]. From the second rhymed word on, we can read a metaphor for the process of physical unification: "(Cloth of) finest linen" at first - finest linen is half transparent summer fabric of high quality - is not only fine but can also be very sexy. ('White linen' in the first poem becomes 'green linen' [自紵-綠紵].) The "rain” (the idiom 'love of cloud and rain'[雲雨之情], shortly cloud and rain [雲雨] is in East Asian cultural space an old metaphor for sexual intercourse which is based on a myth of metamorphosis: a king has in his dream slept with a woman of exceptional beauty, and at parting she said, she will always be there in the morning as a cloud and in the evening as rain. (Here the 'red rain', rain of flowers, in the first becomes 'windy/stormy rain'[紅雨-風雨]. It alludes to passion and at the same time risk.) The third rhymed word is "dance": This couple now is in such joy, - for her it is 'sunny dance', and for him 'moon woman's (lovely) dance'[陽舞-哦舞]; sun and moon, yin and yang, together stand for a complete unification, - that they are now - word for word "mocking birds"[鶘墕]. (The image of the mocking bird is in the West and East, earlier and now, quite different: It was a very rare, exotic colorful bird of great charm, not a bird with banal skills of imitation.)

I could - thanks to Faust - give my attention to one of our most important classical works. It was for me a great discovery. And this discovery was only the first of a series; it was followed by one after the other. I got an insight into our own literary tradition that - not only I - Koreans, in the turbulence of difficult 
historic turns, through the process of modernization and industrialization, have so neglected to care for, and that crucial elements in the literary tradition have become broken and remain out of sight. However, such a formal rule has been the very core of our traditional poetry. Shortly: Goethe's magnum opus, apparently one of the canons of world literature, guided me to look into my own tradition.

\section{Discovery of Literature from the Neighborhood}

By this chance my view became broadened and reached neighbors: The huge East Asian cultural space for the traditional classical poetry came into my sight. For example, I reread Genji Monogatari [源氏物語; The Tale of Prince Genji], the outstanding Japanese classic - with a new point of view. Then I came into more awareness:

utsusemino mio kaetekerum kinomotoni

nao hitogarano natsuka sikikana

[Underneath this tree, where the molting cicada shed her empty shell, my longing still goes to her, for all I know her to be.]

utsusemino hani okutsuyuno kikarurete sinobisinobini nururu sodekana

[Just as drops of dew settle on cicada wings, concealed in this tree, secretly, O secretly, these sleeves are wet with my tears.] (Murasaki 1938)

The theme of this dialogue in the fifth story of the first part is transience (Vergänglichkeit) and its subject-matter is fine cloth: the cloth taken off for the disappointed lover remains as a proof of love. Here a woman weeps with the name Utsusemi [the singing cicada]. She is mourning for a chance of love which forever passed because of her ethically burdened hesitation. Here are two fine objects present - Utsusemi, the empty body of the singing cicada with the fine net wing and sodekana, by tear-wetted sleeve of the cloth of the woman in the grave - are sublimely woven. And above all sikikana, longing, is swinging. The fine whispering sound, similar to that of the fine net wing of a singing cicada, remains, awakening the transience of life: Utssemi-Utssemi, sikikana-sodecana. (From the point of view of Western poetry it could be a very common rhetorical figure. For me it was a discovery.) Not earlier, but now, I could see how finely and subtlly the cloth was depicted. 
$\mathrm{CHON}$

Yes, I was able to deepen my understanding of the neighbor's literature: I read more Chinese classics, for example, the drama Xixianji [西廂記: West Wing Tale] from the $11^{\text {th }}$ century. Now I could read it with much more understanding than earlier, and such a book is no more something archaic or obsolete for me. Now I could examine how skillful the classic's wording is and how subtle its cross references are. Layers on layers were to be excavated - thanks to its outstanding depiction itself and its long-lasting legacy. A dialogue for example:

Tschang:

月色溶溶夜，花陰寂寂春；如何臨皓 魄不見月中人

[In der Nacht des quellenden Mondlichts [In the night of pouring moonlight

Ist im Frühling der Blütenschatten einsam. In spring the flower shadow is lonely.

Ach, was soll man tun?

Ah, what shall one do?

Im Mond fehlt die Mondfrau.]

Not anymore seen is the woman in

the moon.]

Yingying:

蘭閨久寂寞, 無事度芳春; 料得行吟者, 應憐長歎人

[Im Tochterpavillon herrscht ewige Einsamkeit, [The daughter pavilion domains loneliness Ohne jegliche Ereignisse vergeht der schöne Frühling; Nothing happens; lovely spring goes by.

Der Wanderer, der drüben Rezitiertende, A stranger, reciting over there

Hegt Mitleid mit der Langseufzenden.] Has pity with whom sighing long here.]

(Wang 2007: 34)

The end rhyme here opened for me an ocean of metaphors in traditional East Asian literature. Here at first is the myth of the moon goddess Hang-A: according to the myth, the most beautiful woman in the world was not content with her beauty, she stole and took the forbidden beverage of immortality. As she became banished, she fled to the moon and lived there in the 'Palace of Great Cold'. According to a quote from Xixiangji the "woman in the moon", the moon goddess shall not stay lonely any more in that cold palace, i.e., she is just here - as the real girl whom the boy adores. Of such an immortal beauty she is. She describes herself as a person who is "sighing long". In this way she agrees with him and - through rhyme - supports him powerfully. Moreover, she admires his poem and claims that even "silk palindrome" isn't competitive.

吟得句兒匀 念得字兒眞 詠月新詩 繁强似織錦回文

[Gereimte Verse liest man

Wort um Wort vor.

Seinem aufweckenden Gedicht über den Mond Ist vergleichbar jenes Seidenpalindrom?]
[Reciting rhyme verses

Word for word

To his awakening poem on moon

Uncomparable even that silk palindrome]

(Wang 2007: 49) 
The silk palindrome here in comparison is a very long poem woven in silk: according to a legend, a man had to depart from his beloved wife and went to build the Chinese Wall. Waiting for her beloved husband for many, many years in vain, the wife wove silk and sew 840 Chinese characters into it. This wonderful poem of longing is not only itself admirable; but it also can be read in the reverse - quite equally wonderful and of the same meaning. (Not simply 'Roma' and 'Amor', but 840 words full of meaning!) So perfect the verses must have been; but, unfortunately, they do not exist anymore, or, from the beginning onwards. This mythical palindrome is a kind of Platonic idea of the perfect poetic work, but this idea, for example, came very late into my view. The idea came late to me, but it had become a valuable gem for me.

\section{Towards the Margins}

This kind of discovery encouraged me, and I went further: the theme, power of poetic words, does not remain restricted to the German poet Goethe or East Asia. I noticed more and more the "margins" of world literature: for example, I became aware of a poet from Lebanon Fuad Rifka (Chon 2013: 107-109), because I could read from him about Heidegger's reflections on poetry, even if the poems are written in Arabic and rooted in Arabian thoughts; that was a great charm for me. (The poet worked on Heidegger for twenty years, writing his dissertation on him.)

I became aware of a poet in Jerusalem Manfred Winkler (ibid. 130-147) who wrote poems - amid Hebrew, their foreign mother tongue, the official language - still in German, in the language of - I quote Paul Celan - murderers, "Mördersprache" (Celan 1983: 20). Because he had read in his youth books in German and written in German - just like Paul Celan who never lived in Germany but is one of the most outstanding figures in contemporary German literature. Also a Mongolian novelist Galsan Tschinag (Chon 2013: 120-129) came into my view, who originally was a shaman and chief of a tribe still without letters, but he came by chance to Germany thanks to the DAAD scholarship. Thus he writes in German.

So, one after another to encounter such rather hidden authors was meaningful and a great pleasure for me. (I have read a little bit of Jaan Kross; that is what brought me to Estonia. I have read also - thanks to Goethe - Asanaganika (Chon 2011: 166-172), a folk song from Slovenia.)

I thought, I, a Germanist from a small country - who else? - should give more attention and effort to let the world also notice them. Furthermore, I took introducing more Korean works to the world to heart. 
$\mathrm{CHON}$

\title{
Conclusion
}

Surely it will be an unrealistic hope if I wished that the world - on its side willingly - learn the small language like Korean, enjoy and correctly estimate the worth of Korean literary works. But through this kind of transfer, as above mentioned, one can bring the diverse parts of the world a little bit together. It's our job.

\author{
Young-Ae Chon \\ chonya@gmail.com \\ Dept. of German \\ Seoul National University \\ Gwanak-ro 1 \\ Seoul \\ KOREA
}

\section{Bibliography}

Celan, P. 1983. Gesammelte Werke in fünf Bänden. Ed. by B. Allemann, S. Reichert, R. Bücher. Frankfurt a. M.: Suhrkamp, Vol. 3.

Chon, Y. A. 2011. „Sage denn, wie sprech" ich auch so schön?" Zur Macht der Poesie bei Goethe. Göttingen: Wallstein.

Chon, Y. A. 2013. Grenzgänge der poetischen Sprache. Würzburg: Königshausen \& Neumann.

Goethe, J. W. 1994. West-östlicher Divan. Sämtliche Werke. Briefe Tagebücher und Gespräche, I. Abteilung Bd. 3/I. Frankfurt am Main: Deutscher Klassiker Verlag.

Goethe, J. W. 2001. Faust. A Tragedy. Trans. W. Arndt. New York/London: W. W. A Norton.

Goethe, J. W. 2005. Faust, Part II. Trans. D. Constantine. New York: Penguin Classics.

Murasaki, Shikibu. 1938. 源氏物語[Genjemonogatari]. Ed. by Yosano Akiko. Tokyo: Kadokawa Books, http://www.genji.co.jp/yosano/yy03.html (18.12.2018).

Murasaki, Shikibu. 2014 [1966]. Die Geschichte von Prinzen Genji. [Genji monogatari] Ein Liebesroman aus dem 11. Jahrhudert. Zürich: Manesse Verlag.

Wang, Shifu. 1926. Das Westzimmer [Xixiangji]. Ein Singspiel in deutscher Sprache. Peking / Leipzig: Pekinger Verlag.

Wang, Shifu. 2007. 新刊大字魁本全相參增奇妙註釋西廂記[Xixiangji]. Reprinted. Shijianzhuang: Hebeijianpyuchubanshe. 